\title{
Adult Mumps Orchitis - Undiagnosed and Undereported
}

\author{
Abishai Jebaraj ${ }^{1}$, Vinay S Kundargi ${ }^{2}$, Santosh Patil ${ }^{3}$, Basavesh S Patil ${ }^{4}$ \\ ${ }^{1}$ Post Graduate Student, Department of Urology, Shri B M Patil Medical College Hospital and Research Center, Bijapur, \\ Karnataka 586103, 2Professor and Head of the Department, Department of Urology, Shri B M Patil Medical College Hospital \\ and Research Center, Bijapur, Karnataka 586103, ${ }^{3}$ Assistant Professor, Department of Urology, Shri B M Patil Medical College \\ Hospital and Research Center, Bijapur, Karnataka 586103, ${ }^{3}$ Assistant Professor, Department of Urology, Shri B M Patil Medical \\ College Hospital and Research Center, Bijapur, Karnataka 586103, India
}

Corresponding author: Abishai Jebaraj, Department of Urology, Shri B M Patil Medical College Hospital and Research Center, Bijapur, Karnataka 586103, India

DOI: http://dx.doi.org/10.21276/ijcmsr.2020.5.2.15

How to cite this article: Abishai Jebaraj, Vinay S Kundargi, Santosh Patil, Basavesh S Patil. Adult mumps orchitis - undiagnosed and undereported. International Journal of Contemporary Medicine Surgery and Radiology. 2020;5(2):B66-B68.

\section{A B S T R A C T}

Introduction: Mumps is a self-limiting viral infection of the salivary glands that usually manifest as swelling of the parotid gland. Meningitis/encephalitis is a well-known complication of mumps, but involvement and infection of the testis in adolescent boys and adult men are rare.

Case report: We report two cases of mumps associated epididymo-orchitis. The diagnosis was confirmed clinically and serologically by IgG and IgM titers. The symptoms were resolved after the administration of anti-inflammatory and pain medications.

Conclusion: Adult mumps orchitis still remains a major health concern as it may lead to subsequent male subfertility. Management is mainly conservative. Immunization remains the best policy to avoid such complications

Keywords: Mumps, Orchitis, Testicular Involvement, Epididymoorchitis

\section{INTRODUCTION}

Mumps is a self-limiting viral infection of the salivary glands that usually occurs during childhood. It usually manifest as swelling of the parotid gland. Testicular symptoms are commonly noticed during the first week after the parotid infection. Commonly seen local symptoms are testicular pain, tenderness, and scrotal redness. In severe cases, general symptoms such as nausea, vomiting, fever and chills may be seen. ${ }^{1,2}$ The most common pathologic type of mumps orchitis is the interstitial type, which is characterized by interstitial edema and mononuclear infiltration. ${ }^{3}$ Increased intra testicular pressure leads to atrophy in $40-70 \%$ of cases. Testicular atrophy may cause sterility in $37-87 \%$ of these cases. ${ }^{3}$ Color Doppler USG shows vascularity and helps differentiate inflammatory lesions from other acute scrotal diseases. Testicular hyperemia is the most valuable color Doppler US finding in orchitis and epididymoorchitis. ${ }^{4,5}$ Although it is seen worldwide, reports of its outbreaks from India are sparse. Reports of mumps associated orchitis from India are limited. We hereby report two cases of mumps associated epididymo-orchitis that were managed at our center.

\section{CASE REPORT: 1}

A 32 year old patient presented to us with spontaneous painful left hemi scrotal swelling. He had a history of fever with associated bilateral parotid swelling one week prior, for which he had underwent medical treatment from a local hospital and relieved symptomatically. There was no history of dysuria or urethral discharge. There was no history of close contact with any known case of mumps. His anti-mumps vaccination status was not known.

On examination, the left testis was enlarged measuring $8 \mathrm{~cm}$ $\times 7 \mathrm{~cm}$ and tender along with tenderness of left epididymis and cord. The right testis and cord were normal. There were no visible signs of inflammation noted. Scrotal USG was done which showed left edipidymo-orchitis with associated left funiculitis and left mild hydrocele. Both kidneys and bladder were found to be normal by USG abdomen.

Lab investigations showed that the WBC count was raised to 17,190 cells $/ \mathrm{ml}$. Renal parameters and urine culture were normal. The diagnosis was then confirmed with positive serologic test for Mumps IgM (54.2 U/ml) and IgG (>150 $\mathrm{U} / \mathrm{ml}$ ) anti body titres.

Taking into consideration of the history of mumps parotitis, clinical presentation and elevated mumps antibodies, a diagnosis of mumps orchitis was made. The patient was symptomatically treated with analgesics, anti-inflammatory drugs and bed rest with scrotal support.

\section{CASE REPORT: 2}

A 21 year old patient presented to us with spontaneous painful left hemi scrotal swelling associated with high grade fever. The patient did not have any history of dysuria or discharge 
per urethra. However, he had a history bilateral swelling of parotid glands 10 days prior for which he underwent treatment in an outside hospital with symptomatic relief. There was a positive contact history with a known case of mumps, his brother who was diagnosed of bilateral mumps parotitis. The anti-mumps vaccination status of the patient was not known.

Local examination showed tender enlargement of left testis measuring $7 \mathrm{~cm} \times 6 \mathrm{~cm}$ with associated tenderness of left epididymis and cord also. The right testis and cord were normal with no visible signs of inflammation. Scrotal USG showed left edipidymoorchitis with left funiculitis and left mild hydrocele. Both the kidneys and bladder were found to be normal by USG abdomen. Lab investigations showed

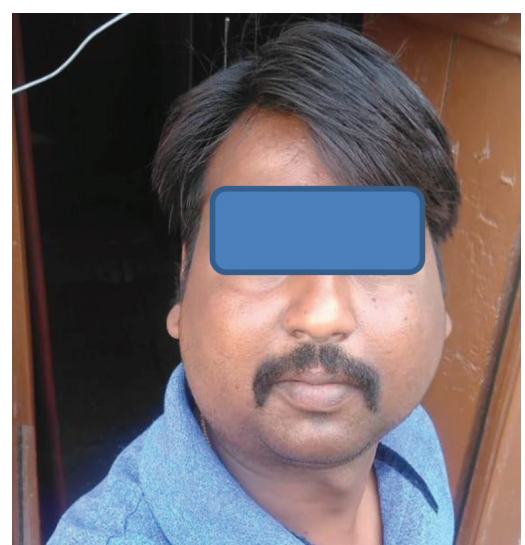

Figure-1: Bilateral Parotid Swelling

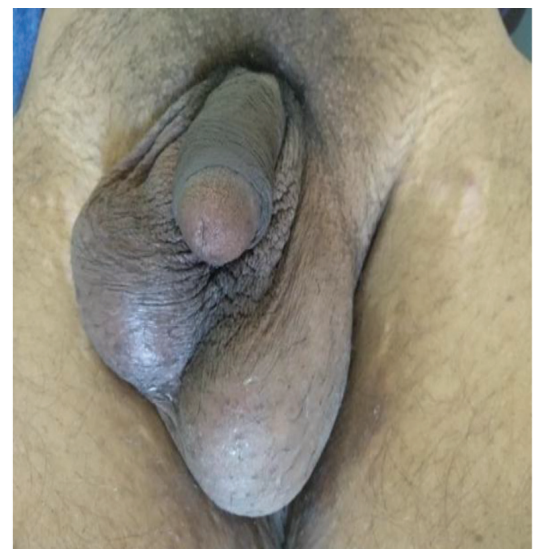

Figure-2: Left Testicular Swelling

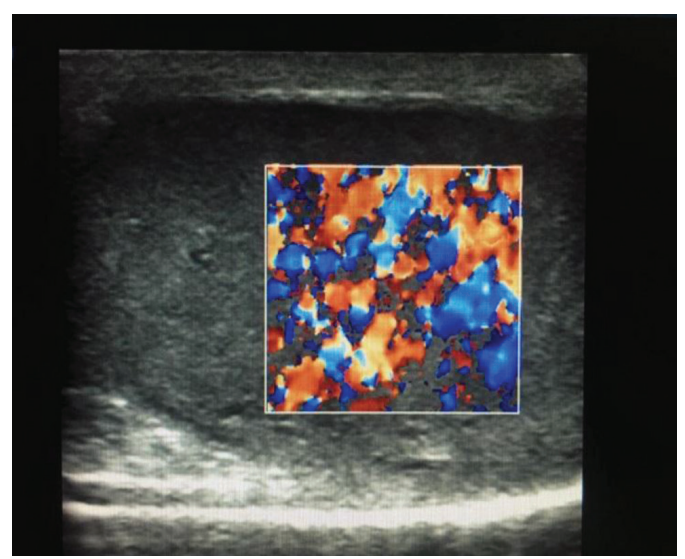

Figure-3: Ultrasound picture of Epididymoorchitis raised WBC count $(13,380$ cells $/ \mathrm{ml})$. All renal parameters and urine culture were normal. The diagnosis was confirmed with positive serologic test for mumps IgM (83.17) and IgG antibody (102.81).

Considering the history of mumps parotitis, clinical presentation and mumps serology, a diagnosis of mumps orchitis was made. The patient was treated with antibiotics, analgesics, anti-inflammatory drugs, and bed rest with scrotal support.

\section{DISCUSSION}

Mumps is caused by an enveloped, non-segmented, negativesense RNA virus belonging to Paramyxoviridae family. Mode of transmission is usually by direct contact, airborne droplets or fomites contaminated with saliva. Mumps is characterized by painful inflammatory symptoms, including parotitis. Mumps IgM ELISA is usually positive in the acute phase of illness and is diagnostic. In addition, seroconversion or fourfold raise of $\operatorname{IgG}$ titers is also considered diagnostic. Mumps, despite being a widely prevalent all over the country is often neglected and under reported. Published literature on mumps orchitis from India are sparse, with the last being published in 2015 by Chandrashekar et al. ${ }^{6}$

Orchitis in mumps usually occurs in post pubertal men and is rare in children. The mechanism behind the development of mumps orchitis has been hypothesized to have due to lymphocytic infiltration and destruction of periductal cells leading to blockage of semeniferous tubules. ${ }^{7}$ Upto 20 to $30 \%$ of adult cases develop subsequent orchitis after 1-2 weeks of parotitis presentation. ${ }^{7} 30-50 \%$ of mumps orchitis patients are reported to develop testicular atrophy which can lead to subfertility due to oligospermia, azoospermia or asthenospermia or even sterility in as high as $13 \%$ of the cases. ${ }^{8} 30 \%-87 \%$ of patients with bilateral mumps orchitis experience infertility.

Mumps orchitis is diagnosed clinically in most cases by white blood cell count, and differential counts are usually normal. A full blood count can show a leucocytosis or a leucopenia and a raised C-reactive protein level (mean 140 $\mathrm{mg} / \mathrm{L}){ }^{9}$ Investigations should always include urine analysis, with culture and sensitivity, to exclude bacterial infection. A diagnosis of mumps orchitis should be considered in patients with orchitis and normal urine analysis, negative urethral cultures and negative midstream urine. Typical ultrasonography features include diffuse hyper-vascularity and increased volume of the testes and epididymis, and an overall hypoechogenicity. ${ }^{10}$ Other associated features found on ultrasonography include swelling of the epididymis and hydrocele formation. Ultrasonography findings are variable and not specific. It is recognized that echo colour Doppler ultrasonography is more sensitive than ultrasonography alone for detecting testicular inflammation. ${ }^{11}$

Treatment is mainly supportive with bed rest, analgesics and scrotal support. Some studies support prescribing broad spectrum antibiotics because bacterial infection of the oedematous testicular tissues cannot always be ruled out. Steroid can help in diminishing pain and oedema, but it does not alter the clinical course of the disease or prevent future complications. 


\section{CONCLUSION}

Sporadic cases of mumps and its associated complications like adult mumps orchitis are being under reported in our country. Adult mumps orchitis still remains a major health concern as it may lead to subsequent male subfertility. Management is mainly conservative. Immunization remains the best policy to avoid such complications.

\section{REFERENCES}

1. Baum SG, Litman N. Mumps virus. In: Mandel GL, Bennet JE, Dolin R, eds. Principles and practice of infectious diseases, 4th ed. New York: Churchill Livingstone, 1995:1496-1501

2. Cotran RS, Kumar V, Robbins SL. Male genital system. In: Pathologic basis of disease. Philadelphia: WB Saunders, 1989:1105-1106

3. Nistal M, Paniagua R. Inflammatory disease of the epididymis and testis. In: Nistal M, Paniagua R, eds., Testicular and epididymal pathology. New York: Thieme-Stratton, 1984:263-277

4. Fitzgerald SW, Erickson S, De Wire DM, et al. Color Doppler sonography in the evaluation of the adult acute scrotum. J Ultrasound Med 1992;11(2):543-548

5. Horstman WG, Middleton WD, Melson GL. Scrotal inflammatory disease: color Doppler US findings. Radiology 1991;179(4):55-59

6. Chandrashekar P., Sathiasekar A.C., Namaratha K., Singarayan J.L., Gnanam A.P. A rare case of mumps orchitis. J Pharm Bioallied Sci. 2015;7(6):773-775.

7. Bartak V. Sperm count, morphology, and motility after unilateral mumps orchitis. J Reprod Fertil 1973;32(4):491-3

8. Berhrman RE, Kliegman RM, Jenson HB, eds. Nelson Textbook of Pediatrics, 17th edn. Philadelphia: Saunders, 2004

9. Muhlemann K. The molecular epidemiology of mumps virus. Infect Genet Evol 2004; 4(1): 215-9

10. Basekim CC, Kizilkaya E, Pekkafali Z, Baykal KV, Karsli AF. Mumps epididymoorchitis: sonography and color Doppler sonographic findings. Abdom Imaging 2000; 25(6): 322-5

11. Tarantino L, Giorgio A, de Stefano G, Farella N. Echo color Doppler findings in postpubertal mumps epididymo-orchitis. J Ultrasound Med 2001; 20(1): 1189-95

Source of Support: Nil; Conflict of Interest: None

Submitted: 19-02-2020; Accepted: 06-05-2020; Published online: 02-06-2020 